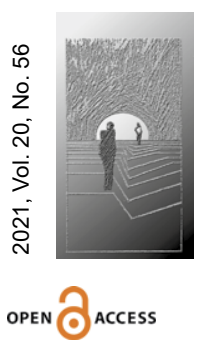

Rastislav Nemec

http://orcid.org/0000-0002-6920-6395 WOS ID AAC-4342-2021

SCOPUS ID 26325736000

University of Trnava, Faculty of Theology rastislav.nemec@truni.sk DOI: $10.35765 / h w .2186$

\title{
The Idea of "Depth" in Ignatian Pedagogy in Face of some Tendencies of Digital Education
}

\begin{abstract}
RESEARCH OBJECTIVE: The aim of this study is to present some contradictory tendencies and draw attention to two phenomena that prove their contradiction. The first one is the missing dimension of depth of knowledge which suggests that the ubiquitous source of information and student awareness is not automatically a qualitative asset. On the other hand, the gradual digitalization of education increasingly indicates the fragmentation of such a teaching process.
\end{abstract}

THE RESEARCH PROBLEM AND METHODS: The article intends to emphasize the importance of two pillars of Jesuit pedagogy, which historically date back to the Spiritual Exercises of St. Ignatius and which were revived by the interpretations of two former superiors of the Society of Jesus, P. Arrupe and A. Nicholas. However, the present times seems to bring different goals in the perspective of digital media and professional profiling of the student.

THE PROCESS OF ARGUMENTATION: The article is structured as follows. In the first part, the author presents the conclusions resulting from some research and measurements conducted in Slovakia in recent years, which aimed at examining students' skills in reading comprehension and indicates the growing support for the digitalisation of education in Slovakia, which the author (and not only he) perceives as highly contradictory. On the other hand, the article makes an attempt to counter the notions: the "reference to depth" and the integrity of the human being, more and more often mentioned in the literature. Through this call for "digital minimalism" it encourages deeper concentration.

RESEARCH RESULTS: The present study is to demonstrate that Jesuit pedagogical appeal to the need for "integral" development of the person and "depth" is extremely actual in this field.

CONCLUSIONS, INNOVATIONS, RECOMMENDATIONS: The aim of the study is to show the need to re-develop these threads of depth and integral development of the human being, along with other pillars of Jesuit education, and rethink its message.

$\rightarrow$ KEYWORDS: DIGITAL ERA, EDUCATION, NON-LINEAR READING, JESUIT

PEDAGOGY, IGNATIAN EDUCATION 


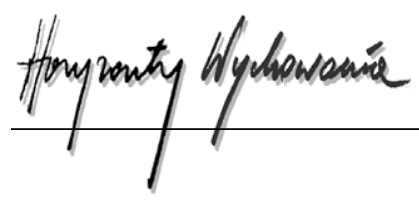

\section{STRESZCZENIE}

Idea „głębi” w pedagogice ignacjańskiej a wybrane tendencje edukacji cyfrowej

CEL NAUKOWY: Celem niniejszego opracowania jest przedstawienie niektórych sprzecznych postaw oraz zwrócenie uwagi na dwa zjawiska, które świadczą o ich sprzeczności. Jednym z nich jest brakujący wymiar głębokości wiedzy, który sugeruje, że wszechobecne źródło informacji i świadomości studentów nie gwarantuje jakości zdobywanej wiedzy. Z drugiej strony, stopniowa cyfryzacja edukacji coraz bardziej wskazuje na fragmentaryzację takiego procesu nauczania.

PROBLEM I METODY BADAWCZE: Artykuł zamierza podkreślić znaczenie dwóch filarów pedagogiki jezuickiej, historycznie sięgających Ćwiczeń duchowych św. Ignacego, które zostały ożywione przez interpretacje dwóch byłych przełożonych Towarzystwa Jezusowego, P. Aruppe i A. Nicholasa. Obecne czasy - jak się wydaje - w perspektywie pojawienia się mediów cyfrowych i profilowania zawodowego ucznia mają jednak inne cele.

PROCES WYWODU: Artykuł jest skonstruowany w następujący sposób: Autor przedstawia wnioski z niektórych badań i pomiarów prowadzonych na Słowacji w ostatnich latach, które miały na celu zbadanie umiejętności czytania ze zrozumieniem przez uczniów oraz wskazuje na rosnące poparcie dla cyfryzacji edukacji na Słowacji, które autor (i nie tylko on) postrzega jako wysoce sprzeczne. Równocześnie artykuł stara się przeciwstawić coraz częściej przywoływanemu w literaturze „odwołaniu do głębi” i integralności osoby ludzkiej. Poprzez to wezwanie do „cyfrowego minimalizmu" zachęca do głębszej koncentracji.

WYNIKI ANALIZY NAUKOWEJ: Niniejsze opracowanie ma na celu wykazanie, że pedagogika ignacjańska odwołująca się do potrzeby „integralnego” rozwoju osoby i „głębi” jest niezwykle aktualna w swoich odwołaniach w tym zakresie.

WNIOSKI, INNOWACJE, REKOMENDACJE: Opracowanie ma na celu ukazanie potrzeby rozwijania na nowo wątków głębi i integralnego rozwoju osoby ludzkiej wraz z innymi filarami jezuickiego wychowania oraz przemyślenia na nowo ich przesłania.

$\rightarrow$ SŁOWA KLUCZOWE:

EDUKACJA CYFROWA, EDUKACJA, CZYTELNICTWO, PEDAGOGIKA IGNACJAŃSKA, PEDAGOGIA IGNACJAŃSKA

\section{The postulate for information literacy and e-education as a long-term educational objective not only in Slovakia}

The Internet offers new, faster ways of learning and processing information. The access to information is becoming easier and more popular, so an increasing number of users reach for it. It was also taken into account in the UNESCO declaration on education, in which one of the most urgent educational objectives for the coming years is "providing schools with digital technologies, digitalization of educational resources, as well as 
introduction of e-learning platforms that overcome the limitations of traditional teaching and promise connectivity" (UNESCO, n.d. - declaration on digital, personalized and lifelong learning to facilitate open, appropriate, people-centered, sustainable and equitable approaches to education). In a more global perspective, this is a revolutionary idea connected with collective intelligence and higher scholarship standards which, due to the digital revolution, "translates all possible and imaginable documents into a virtual, interconnected and omnipresent space" (Fišerová, 2015, p. 134). The scope of knowledge which is, in this way, available both for the teacher and student, becomes the basis for incredible creativity and a broad fundament of a potential to be used in practice, in the process of education.

Apart from the general appearance of digitalization and electronic media, science makes other progress. Within the last two years, the media announced that scientists invented a new kind of writing which radically changes the old, established alphabetical writing. In their opinion, due to this invention we will be able to read and learn faster. This new font is called Sans Forgetica, and it was invented in the Royal Melbourne Institute of Technology (RMIT). The font works through a brain training and uses its possibilities in the areas, in which it was neglected. It means that the scientists removed parts of particular letters, which unnecessarily "hold" an eye and brain while reading, and which can be freely completed by the brain (Porubský, 2018). This kind of "fast reading" and "fast learning" is symptomatic for our times. Fast thinking and decision-making replace established norms in pedagogy and education. Thus, the ability to acquire information quickly is not "hindered" by the redundant number of letters (vowels). Therefore, can we rightly ask if the common denominator and the only criterion of effective learning is the accessibility and speed of receiving and processing information?

Apparently, in Slovakia (but not only here) we are witnessing two contradictory tendencies. One of them is the general digitalization of education, which aims at developing students' computer skills and including IT technologies into the process of education, as this will increase learning opportunities and make the educational process more interesting. The objective of such digitalization is the opportunity to become "practically" involved in the process of education, also in a more active and creative manner. On the other hand, this general tendency for digitalization has some disturbing consequences in the form of the lack of concentration and worse results in reading comprehension. This may result from the fact that digital media are included in the process of education which does not fully support the "depth" of learning and distracts students' attention.

\section{Vision and justification of the sense of "depth" and integrity}

Despite the fact that digital media seem to be the future, we must agree with an interesting analysis carried out by Cal Newport, and his conclusions described by him in a book entitled "Deepwork." In his opinion, the increase in "Internet-centrism" (a term invented by Evgeny Morozov) is a phenomenon based on the belief that all what is "high-tech" is 


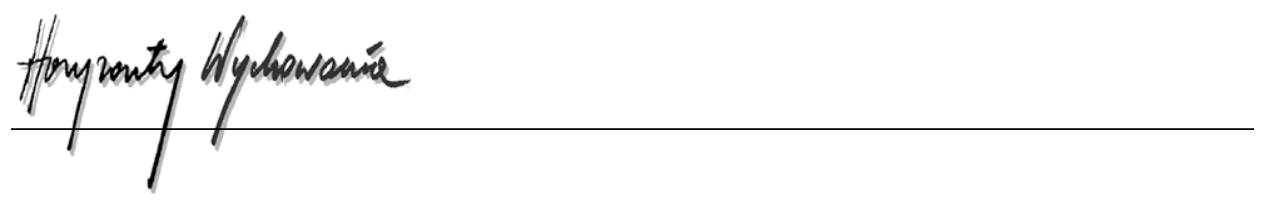

good and beneficial, and all that fails to go with the times can be defined as "dysfunctional and obsolete". This is an interesting view, which matches with the old statement by Neil Postman that, in case of the technological boom, we often fail to see the alternatives and we even omit them on purpose, choosing the uniform path. The technological boom only brings us one option which, in consequence, ends with uniformization and "shallowness." Shallowness and "computerization," which are connected with IT technology, include superficial knowledge which lacks foundations (according to the authors: Spitzer, 2014; Spitzer, 2016; Bauerlein, 2008).

For Cal Newport it is important to realize that the phenomenon of the future will not only be the acquisition of the ability to count and use a computer, but a "deep" attitude the depth of science and work, as well as the ability to focus on a particular action combined with an untiring search for a solution. Newport believes that deep concentration is now in a very unfavourable situation due to today's era of the Internet. Deep concentration is based on quality, slow and honest approach, while the Internet offers "easier" and "faster" solutions, "drawing students away" from their work. Promoting deep concentration, in turn, requires the rejection of many modern IT technologies (Newport, 2016, p. 42).

This idea is also supported by some psychologists who claim that what gives meaning to the learner are activities related to deep concentration as they provide the student with intensive experience. For example, Mihaly Csikszentmihalyi is a psychologist who says that when we concentrate on an activity, we experience greater intensity than when we do nothing (Csikszentmihályi, 1996, pp. 13-14). Comparing to the classical models which analyse the sense of happiness, the author does not claim that a person is happy when he/she does not do anything. He presented a thesis that is contradictory to the previous statements. While working and "struggling" with a problem, we feel greater intensity than while choosing an easier way - a day off, relax or inactivity. M. Csikszentmihalyi calls this concept a theory of "flow."

The opinions of both of those authors lead to one conclusion: digital technologies and the digital era force us to act faster. With the kinds of impulses it offers, it places us among many tasks at the same time - while focusing on many things, we are unable to perform them in a "deep" manner.

\section{Ignatian pedagogy based on two principles: depth and a person's integrity}

O'Malley separated elements (O'Malley, 1993, 279-280) which contributed to the original and further success of the Jesuits, and to the creation of a new and international pedagogical style. Here are two of those elements that I would like to emphasize:

1. Jesuits provided more responsible education and they were better motivated than most teachers in schools that functioned before the universities in Europe. Also, Jesuits tried to influence students with their life rather than with words. 
They had a different approach and they treated a student as a whole. In this sense, Jesuits cared for the development of the whole personality and not just for one of its aspect.

2. Such approach was connected with humanism in the Jesuit pedagogy. Humanism is derived from the interest in a human being, and such interest has practical implications in the pedagogical context. Contrary to university education, studia humanitatis cared for "ethical, spiritual, religious, emotional, as well as physical development of students." A human being, as one of the key subjects of humanism, eventually becomes an integral part of Ignatian spirituality, which perceives a person's dignity through the Christological context of the Incarnation. At the same time, such spirituality perceives a human being in the context of the sanctity of the relationship of love which God maintains with His creation (Ignác z Loyoly, 2005, pp. 30-31) and to which a person only responds at the moment (Jeník, 2015, pp. 13-14). Jesuits always emphasized the importance of love for their students, individual knowledge of them, as well as relationships based on respect for them. Such a "deep" relationship at the beginning makes it possible to transfer this "depth" for later.

Apart from those historical circumstances, it is worth thinking about the recent interpretation which is always suggested by the superiors of the Society of Jesus, e.g. Pedro Arrupe (†1991).

\section{Ignatian pedagogical paradigm of a person's integrity}

This paradigm will be presented here as an attitude which is generally called the "Ignatian pedagogical paradigm." It is an approach to teaching and learning which St Ignatius outlines in his Spiritual Exercises (Ignác z Loyoly, 2005, pp. 31). Just like the objective of the Spiritual Exercises is to support one in an active response to the Lord's call in prayer, the objective of the Ignatian pedagogical paradigm is to enable the student to develop the mind's habits and creative answers.

According to P. Arrupe, this paradigm may create a strong culture of education in our schools. Such culture can, to a certain degree, balance the influence of the individualistic consumer culture on young people. Arrupe admits that a human being "with his/her conscience, intelligence and abilities, is truly in the centre" of education (Arrupe 1980, p. 134). What is important, however, is that a person is "a centre called to come out of themselves (exsistere), to give themselves to others in love which is their ultimate and overwhelming dimension as it gives meaning to all their other dimensions" (Arrupe 1980, p. 134).

Relationships among people are the basis for the development of a person as a whole - in all his/her aspects - in the environment which is a palette of relationships. A relationship is at the beginning of human life and at the end of it. A person is born into relationships, which results in the fact that in education it is important to continue a whole 


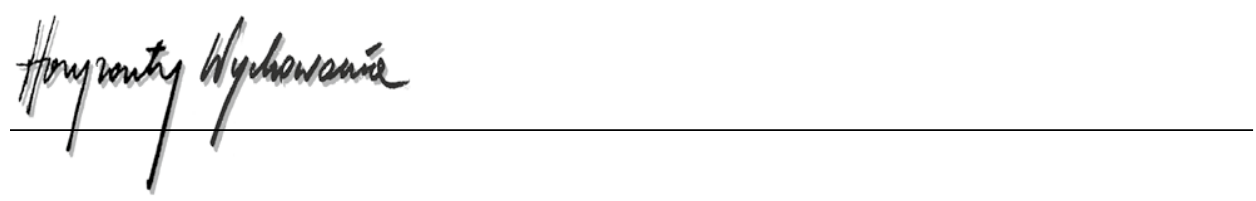

person's development in relationships. This will make it possible to develop a person as a whole - not as particular parts separately (separately intellectual and psychological, separately spiritual, separately the emotional part, etc.), but all the parts at the same time. Relationships constitute the whole personality, moving it forward towards maturity. That is why, it is important for a student to identify himself/herself based on those relationships and toconfront with them (also with his/her spiritual and psychological attitudes and behaviour), what can facilitate their development and growth. Jacob A. O'Donnell quotes P. Arrupe, saying that Jesuit education is focused on the student. Its objective is the creation of an independent and responsible student who is skilful, able to function independently, and willing to take up various actions in a responsible manner (Arrupe, 1981b, p. 470).

P. Arrupe also explains that "the objective of our schools is not educating little academic monsters who are dehumanized and introvert. We do not want to raise pious bigots who are indifferent to the world in which they live and unable to take responsibility for it". Instead, the objective of education is to form people who are "calm, cheerful and persistent, and open to everything that is human" (Arrupe, 1981b, p. 64). It means that human values, which are to be instilled in the students, i.e. "academy, Gospel, service, openness, sensitivity to the present and the future," are to be "mixed in a balanced manner," form reasonable people (Arrupe, 1981b, p. 64). Simply speaking, this is a formation of a "whole person" (Arrupe, 1981b, p. 77) in the "intellectual, artistic, moral, and religious sense" (Arrupe, 1981a, p. 87).

\section{Paradigm of depth in the output of P.A. Nicolás}

The ideas we presented at the beginning were even more carefully and clearly analysed by the general superior A. Nicolás in his speech entitled Challenges for Today's Jesuit Education. Although P.A. Nicolás perceives today's communication and IT technologies as positive, he can see a clearer globalization potential in them. Globalization, which he describes as the globalization of superficiality, deeply affects thousands of young people. It is very easy to spread emotions that have nothing to do with arguments. According to P.A. Nicolás, in the same way reactions and opinions may be "copied and pasted" without young people's critical analysis of a given case and without any critical distance. This makes it easier to form further crowds of "promoters" who often use visually effective semiotic tools (pixels, banners, screens). In this sense, it is true that education has been trapped into "pixelculture" from which we cannot escape. Impressive means the same as attractive. However, as Nicolás often emphasizes, those impressions, opinions and general "friendships" in the Internet may easily remain "shallow". What has nothing to do with an interpersonal relationship pretends to be friendship, just like all kinds of "mailing" options pretend to be communication.

This "culture of the majority" encourages the "mentality of the majority" which is more difficult to resist. Moreover, generally speaking, such mentality spreads "the superficiality 
of thoughts, visions, dreams, relationships and convictions" (Nicolás, 2011, p. 2). It is easier to do what others do. It is easier to be a part of a group as someone "equal," someone who does not "stand out." In this case, however, we are not talking about a true development of an individual, but about "copying." And, in the case of such copies, good relationships are not created but distorted.

P.A. Nicolás says that these "global challenges" require deeper analysis, reflection and consideration. He claims that new technologies may promote such values as moral relativism and consumerism, which may both shape and misshape the internal world, especially that of young people. Social trends should not be immediately condemned. Strong emphasis on individual effort does not have to be rejected at once. Jesuit education does not lead to strong individualism, but encourages human being to individual development, individual choice and decision. On the other hand, it resists powerful global trends, but instead, it encourages people to strong social thinking, empathy and involvement which will bring positive changes.

P.A. Nicolás writes:

Us, teachers, are in the process of changes. There is no true, deep meeting that would not change us. What kind of meeting do we have with our students if we fail to change? And the meaning of a change for our institution consists in "who our students will become" (...). In other words, in Jesuit education the depth of science and imagination encompasses and integrates intellectual discipline with the reflection on the experience of the reality (...). Due to this depth, we are also able to recognize God who already acts in our world (Nicolás, 2011, p. 4).

\section{Conclusions}

In this article we could see that the digital era brings different stimuli that are motivated by the tendency determined by technological progress. The interest in digital media is increasing, which results in changes in the students' perception and concentration.

In its stimuli, Jesuit pedagogy, for several dozen years, has been trying to pay attention to "the signs of time," emphasizing the need for a few educational principles. We chose to analyse two of such principles: the need for a deep, authentic and honest attitude which is disappearing, and the need for an integral development of a whole person - not only of one aspect, whether an intellectual or emotional one.

Teachers in Jesuit schools present academic subjects from the perspective focused on a person, with the emphasis on discovering and analyzing patterns, relationships, facts, questions, observations, conclusions, problems, solutions and implications that a given discipline introduces into what it means to be a human being. In this way, education becomes a carefully justified quest through which a student forms or reforms his/ her habitual attitudes towards other people and the world.

Published as a part the project "Vega 1/0637/20 Podnety zo stredovekej filozofie v dnešnom myslení" 


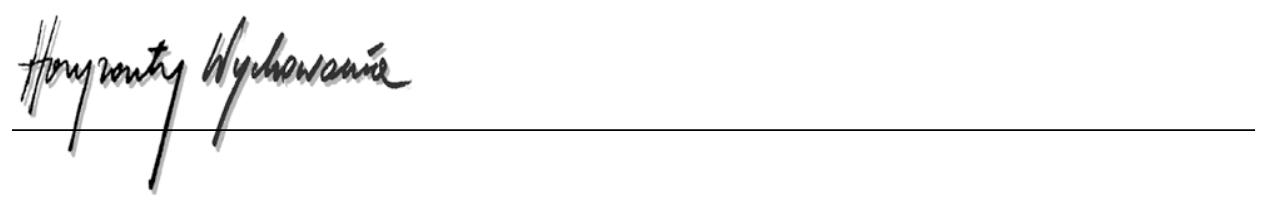

BIBLIOGRAPHY

Arrupe, P. 1980. Men for others: Address to Jesuit alumni of Europe in Valencia. In J. Aixala (Ed.), Justice with faith today (pp. 123-138). Anand: Anand Press.

Arrupe, P. (1981a). Jesuit mission in the university education. In J. Aixala (Ed.), Jesuit apostolates today (pp. 80-95). Anand Press.

Arrupe, P. (1981b). Our secondary schools today and tomorrow. In J. Aixala (Ed.), Jesuit apostolates today (pp. 55-78). Anand Press.

Bauerlein, M. (2008). The dumbest generation. How the digital age stupefies young Americans and jeopardizes our future (or, don't trust anyone under 30). Tarcher/Penguin.

Csikszentmihályi, M. (1996). O štěstí a smyslu života. Mužeme ovládat své prožitky a ovlivňovat jejich kvalitu (E. Hauserová, Trans.). Nakladatelství Lidové noviny.

Fišerová, M. (2015). Kybernetické imaginárno. Rozhovor s Pierrem Lévym. In M. Fišerová (Ed.), Obraz a moc. Rozhovory s francouzskými mysliteli (pp. 134-140). Karolinum.

Jeník, L. (2015). K teoretickým východiskám jezuitského vzdelávania. Studia Aloisiana, 6(4), 5-27. Ignác z Loyoly. (2005). Duchovné cvičenia. Dobrá kniha.

Newport, C. (2016). Deep work. Rules for focused success in a distracted world. Grand Central Publishing.

Nicolás, A. (2011). Challenges to Jesuit higher education today. Conversations on Jesuit Higher Education, 40, Article 5. http://epublications.marquette.edu/conversations/vol40/iss $1 / 5$

O’Malley, W.J. (1993). Los primeros jesuitas (J.A. Montero Moreno, Trans.). Mensajero.

Porubský, Š. (2018, October 5). Sans Forgetica - nový font, vd'aka ktorému sa naučite texty omnoho skôr. Techbox. https://techbox.dennikn.sk/sans-forgetica-novy-font-vdaka-ktoremu -sa-naucite-texty-omnoho-skor/?ref=mpm

Spitzer, M. (2014). Digitální demence (F. Ryčl, Trans.). Host.

Spitzer, M. (2016). Cyberchoroby. Jak cyfrowe życie rujnuje nasze zdrowie (M. Guzowska-Dąbrowska, Trans.). Wydawnictwo Dobra Literatura.

UNESCO. (n.d.). The Education 2030: Incheon declaration and framework for action. http://uis. unesco.org/sites/default/files/documents/education-2030-incheon-framework-for-action-implementation-of-sdg4-2016-en_2.pdf

\section{Copyright and License}

This article is published under the terms of the Creative Commons Attribution - NoDerivs (CC BY- ND 4.0) License http://creativecommons.org/licenses/by-nd/4.0/ 